https://doi.org/10.11646/zootaxa.4324.3.9

http://zoobank.org/urn:lsid:zoobank.org:pub:AF52E5F5-6C6A-4382-89C9-E2A71B7DB4DB

\title{
Contributions to the knowledge of predaceous midges of the subgenus Eukraiohelea Ingram \& Macfie of Stilobezzia Kieffer (Diptera: Ceratopogonidae), from Brazil
}

\author{
CARLA G. CAZORLA ${ }^{1}$, ERICK ARAGÃO CARDOSO ${ }^{2} \&$ MARIA LUIZA FELIPPE BAUER $^{2}$ \\ ${ }^{1}$ División Entomología, Museo de La Plata, Paseo del Bosque s/n, B1900FWA La Plata, Argentina and Consejo Nacional de Investi- \\ gaciones Científicas y Técnicas (CONICET), Argentina. E-mail: carlacazorla@fcnym.unlp.edu.ar \\ ${ }^{2}$ Coleção de Ceratopogonidae, Laboratório de Diptera, Instituto Oswaldo Cruz, Av. Brasil 4365, Manguinhos, $21040-900$ Rio de \\ Janeiro, Brasil.E-mail:mlfbauer@ioc.fiocruz.br
}

\begin{abstract}
Two new species of predaceous midges of the subgenus Eukraiohelea Ingram \& Macfie of Stilobezzia Kieffer are described and illustrated: Stilobezzia (Eukraiohelea) proxima n. sp. and S. (E.) quasielegantula n. sp. The previously known New World species, Stilobezzia (E.) elegantula (Johannsen) is redescribed and illustrated. The species are illustrated through photomicrographs from adult males and females collected in the Brazilian state of Rio de Janeiro. A key to adults of the five American species of Stilobezzia (Eukraiohelea) is also provided.
\end{abstract}

Key words: Ceratopogoninae, Ceratopogonini, taxonomy, new species, Río de Janeiro

\section{Resumo}

Duas novas espécies de ceratopogonídeos predadores do subgênero Eukraiohelea Ingram \& Macfie de Stilobezzia Kieffer são descritas e ilustradas: Stilobezzia (Eukraiohelea) proxima n. sp. e S. (E.) quasielegantula n. sp. A espécie do Novo Mundo previamente conhecidas, Stilobezzia (E.) elegantula (Johannsen), é redescrita e ilustrada. As espécies são ilustradas por microfotografias de machos e fêmeas coletados no estado do Rio de Janeiro, Brazil. É fornecida uma chave dos adultos de Stilobezzia (Eukraiohelea) para as cinco espécies do continente americano.

Palavras-chave: Ceratopogoninae, Ceratopogonini, taxonomia, especies novas, Río de Janeiro

\section{Introduction}

Stilobezzia Kieffer is a large, diverse genus of predaceous Ceratopogonidae, in the tribe Ceratopogonini of the subfamily Ceratopogoninae. Four subgenera are currently recognized: the cosmopolitan Acanthohelea Kieffer and Stilobezzia Kieffer, Debenhamia Wirth \& Grogan, in Australia, and Eukraiohelea Ingram \& Macfie from Africa, America and southeastern Asia.

Species in the subgenus Eukraiohelea are distinguished by their wing with a single, elongate radial cell, short, stout spines on their fore femur and tarsomeres 5 of both sexes with enlarged, stout, setae called "batonnets". Presently, there are 344 species of Stilobezzia, however, only 12 species in the subgenus Eukraiohelea are recognized (Borkent, 2016) of which only three are known from the Neotropical region: S. (E.) amnigena (Macfie) and $S$. (E.) elegantula (Johannsen), known from both sexes, and $S$. (E.) dorsofasciata (Lutz), known from a single female. All three of these species are reported in the Brazilian States of Maranhão, Amazonas and Rio de Janeiro, respectively (Santarém \& Felippe-Bauer, 2017). Stilobezzia elegantula was recorded in the Nearctic region by Wirth (1953) and Wirth \& Grogan (1981), and it is presently known in the USA from Kansas and Maryland, south to Louisiana and Florida (Borkent \& Grogan 2009). Subsequently, Wirth \& Spinelli (1992) noted that S. amnigena 
was misidentified as S. elegantula by Wirth (1953) and Wirth \& Grogan (1981) from Florida and Maryland specimens, and they redescribed and partially illustrated both species, and provided a key to the American species of Eukraiohelea, including $S$. (E.) subsessilis Kieffer, which is now considered a synonym of $S$. (E.) elegantula (Spinelli \& Cazorla, 2005; Borkent 2016).

During field samplings carried out in the Atlantic forest of southeastern Brazil, several species of Stilobezzia were collected, including three in the subgenus Eukraiohelea: Stilobezzia elegantula and two undescribed species. Herein, we describe and provide photomicrographs of the most important diagnostic characters of the two new species and S. (E.) elegantula, as well as a key to adults of the American species of the subgenus Eukraiohelea. Including the two new species described herein, there are now five species of Stilobezzia (Eukraiohelea) in the Neotropics, all of which inhabit Brazil.

\section{Materials and methods}

Specimens were collected with Malaise trap in Union Biological Reserve $\left(22^{\circ} 25^{\prime} 35^{\prime \prime}\right.$ S, 42 $\left.2^{\circ}{ }^{\prime} 4^{\prime \prime} \mathrm{W}\right)$, Casimiro de Abreu, Rio de Janeiro State, Brazil (Fig. 43). Specimens were preserved in glycerin and subsequently cleared, dissected and mounted onto microscope slides in phenol-balsam in the manner described by Wirth \& Marston (1968). They were examined, measured and photographed with a Nikon Eclipse E 200 microscope with a Motican 2300 digital camera and the plates were prepared using GIMP Portable 2.6.

Terms of structures follows those in the Manual of Central America Diptera (Borkent et al. 2009). In males of Stilobezzia the distal three flagellomeres usually differ in length and shape from the proximal 10, so their antennal ratios were obtained by dividing the combined lengths of the distal three flagellomeres by the combined lengths of the preceding 10 flagellomeres.

The holotypes, allotypes and paratypes of the two new species and other specimens studied of $S$. (E.) elegantula are deposited in the Coleção de Ceratopogonidae (FIOCRUZ/CCER), Instituto Oswaldo Cruz, Fundação Oswaldo Cruz, and paratypes of $S$. (E.) quasielegantula are also deposited in the Entomological Collection of the División Entomología del Museo de La Plata, La Plata, Argentina (MLPA).

\section{Results}

\section{Key to the American species of Stilobezzia (Eukraiohelea)}

Females . . .

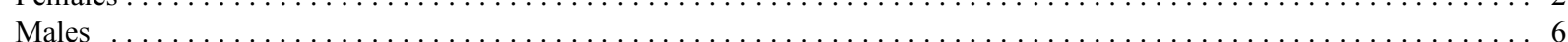

Pale yellowish species; tarsomeres 5 of all legs with the same number of pairs of batonnets $\ldots \ldots \ldots \ldots \ldots$

Pale or darkish species; tarsomeres 5 of all legs with variable numbers of pairs of batonnets. $\ldots \ldots \ldots \ldots \ldots \ldots \ldots$ Tarsomeres 5 of all legs with 2 pairs of batonnets (Fig. 11); fore femur with 2 ventral spines; basal 1/3 of hind femur brown

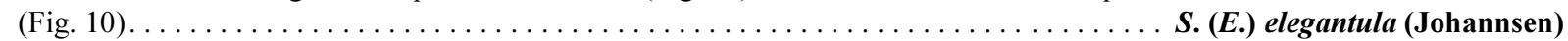
Tarsomeres 5 of all legs with 1 pair of batonnets; fore femur without ventral spines; hind femur uniformly pale ...

S. (E.) dorsofasciata (Lutz) Darkish species; tarsomere 5 of fore leg with 1 pair of batonnets, tarsomere 5 of mid and hind legs with 2 pairs of batonnets .

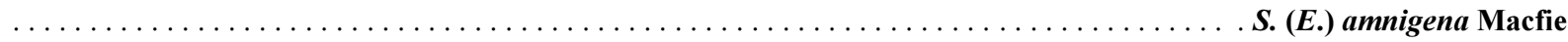
Pale yellowish species; tarsomere 5 of fore and mid legs with 2 pair of batonnets, tarsomere 5 of hind leg with 1 pair of baton-

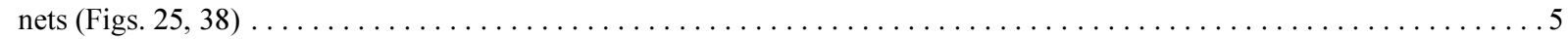
Wing length 1.75-1.82 mm; spermatheca $90 \times 57 \mu$; halter stem and base of knob brown ........ S. (E.) proxima n. sp

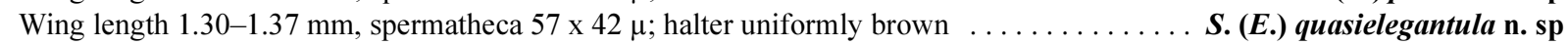
Tergite 9 without apicolateral processes; gonocoxite with proximal portion pale yellowish, distal portion contrasting dark

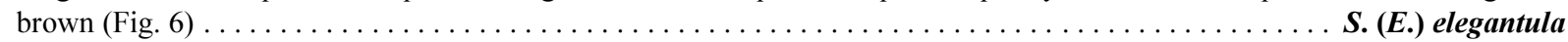
Tergite 9 with apicolateral processes; gonocoxite uniformly brown or pale yellowish $\ldots \ldots \ldots \ldots \ldots \ldots \ldots$

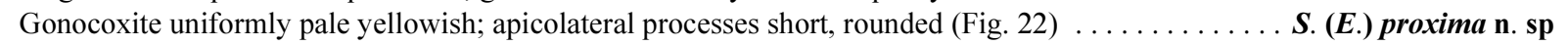
Gonocoxite uniformly brown, apicolateral processes moderately elongate, lobe-like (Fig. 35) $\ldots \ldots \ldots \ldots \ldots$ Gonostylus swollen subapically, apex with a heavily sclerotized, elongate, curved, pointed projection; cerci large, conspicuous

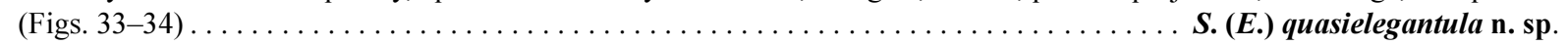
Gonostylus swollen at midportion, apex without a heavily sclerotized, elongate, pointed projection; cerci very small $\ldots \ldots$ 


\section{Stilobezzia (Eukraiohelea) elegantula (Johannsen)}

(Figs. 1-14)

Bezzia elegantula Johannsen, 1907: 109 (female; U.S.A., Kansas).

Probezzia elegantula: Malloch 1914: 137 (combination).

Parabezzia elegantula: Malloch 1915: 359 (combination).

Parabezzia (Eukraiohelea) elegantula: Johannsen 1934: 345 (notes; change of status).

Eukraiohelea elegantula: Johannsen 1943: 781 (combination).

Stilobezzia (Eukraiohelea) elegantula: Wirth 1953: 62 (in part, female; combination; redescription; distr.); Wirth 1974:43 (in Neotropical catalogue; distribution); Wirth \& Grogan 1981: 78 (in part, female; redescription; figs.); Wilkening et al. 1985: 525 (Florida records); Wirth \& Spinelli 1992: 343 (redescription; distribution); Spinelli \& Cazorla 2005: 72 (Argentina, Paraguay records; distribution); Borkent and Spinelli 2007: 86 (in Neotropical catalogue); Borkent and Grogan 2009: 22 (in Nearctic catalogue north of Mexico; distribution); Grogan et al. 2010: 39 (Florida record); Torreias et al. 2014: 117 (Amazon records; distribution); Borkent 2016: 140 (in online catalogue); Santarém \& Felippe-Bauer 2017: 19 (in Brazilian catalogue).

Stilobezzia (Eukraiohelea) maculitibia Lane \& Forattini, 1956: 207 (female, male; Panama); Lane \& Forattini 1961: 84 (in key); Wirth 1974:43 (in Neotropical catalogue; distr.); Wirth \& Spinelli 1992: 344 (as synonym of S. elegantula).

Stilobezzia subsessilis Kieffer, 1917: 311 (female; Paraguay); Lane \& Forattini 1961: 88 (subgeneric position); Wirth \& Spinelli 1992: 348 (as species inquirenda); Spinelli \& Cazorla 2005: 73 (as synonym of S. elegantula).

Diagnosis. The only American species of Stilobezzia (Eukraiohelea) of medium to large size (wing length 1.27$1.48 \mathrm{~mm}$ ) with pale yellowish coloration and distinctive L-shaped dark brown spots on abdominal tergites and basal $1 / 3$ of hind femur brown. Male with proximal $1 / 3$ of gonocoxite pale yellowish and the distal $2 / 3$ contrasting dark brown, and a rectangular sclerite located ventrally at midlength of stem of parameres. Female with two pairs of batonnets on tarsomere 5 of all legs.

Redescription of male. Head (Fig. 1) dark brown. Antenna with flagellomeres 1-10 pale yellowish basally, brown distally, flagellomeres 11-13 dark brown with pale yellowish basal ring; flagellomere 13 nearly twice as long as 12; plume dark brown, dense; antennal ratio 1.09-1.23 (1.17, $\mathrm{n}=7$ ). Palpus (Fig. 2) dark brown; third segment moderately stout with subapical, round shallow sensory pit; palpal ratio $2.37-3.14(2.87, \mathrm{n}=7)$.

Thorax. Scutum brown (as Fig. 8, female), anterolateral margins darker, prescutellar depression pale yellowish; scutellum pale yellowish except narrow lateral margins brown, with 4 stout setae, $0-2$ thinner setae; postscutellum dark brown. Legs pale yellowish; trochanters dark brown; apex of fore tibia dark brown; basal 1/3, narrow apex of hind femur brown; basal 1/3, narrow apex of hind tibia dark brown; fore femur with 2-3 short, stout ventral spines; tarsomere 1 of mid leg with basal, slender, straight spine; tarsomere 1 of hind leg with basal, stout, curved spine; hind tibial comb with 5 spines; fore leg tarsal ratio 2.21-2.63 $(2.34, \mathrm{n}=8)$; mid leg tarsal ratio 2.783.03 (2.87, $\mathrm{n}=8)$; hind leg tarsal ratio 2.40-2.62 (2.49, $\mathrm{n}=8)$; tarsomere 5 of all legs (Fig. 3) with 1 pair of batonnets, claws large, shorter than their respective tarsomere 5 with long basal tooth, hind claws longest. Wing (Fig. 4) membrane hyaline; r-m crossvein oblique; cubital fork distal to level of base of r-m crossvein; wing length $1.27-1.45(1.35, \mathrm{n}=8) \mathrm{mm}$, width $0.44-0.48(0.45, \mathrm{n}=8) \mathrm{mm}$; costal ratio $0.72-0.75(0.74, \mathrm{n}=8)$. Halter stem pale; basal half of knob dark brown, distal half pale.

Abdomen. Pale yellowish, with distinctive dark marks on the lateral margins of the tergites. Genitalia (Figs. 57): tergite 9 extending to apex of gonocoxites, distal margin rounded with small mesal notch; cerci slender, rectangular; sternite $92.80 \mathrm{X}$ broader than long with convex posteromedian projection. Gonocoxite nearly triangular, stout, $1.7 \mathrm{X}$ longer than greatest breadth, proximal $1 / 3$ pale yellowish, distal $2 / 3$ dark brown with a hyaline membrane extending from dorsal inner margin to near apex of parameres, the basolateral margins slightly sclerotized, lobe-shaped, distal margin rounded; gonostylus pale yellowish, slender, $0.75 \mathrm{X}$ the length of gonocoxite, tip curved. Parameres separate, subparallel, heavily sclerotized; basal apodemes stout with stem not reaching margin of tergite 9 ; proximal $1 / 2$ of parameres slender basally, distal $1 / 2$ gradually broadening, apices recurved ventrally, tips pointed (Fig. 7); a rectangular sclerite located ventrally at midlength of stem of parameres. Aedeagus represented by 2 slender, arched sclerites; basal portion heavily sclerotized, curved, basal arms recurved; distal portion sclerotized, apices pointed, overlapping.

Redescription of female (Fig. 8). Similar to male, with the following notable sexual differences. Head (Fig. 9). Antenna with flagellomeres 1-8 pale yellowish basally, brown distally, flagellomeres 9-13 brown with pale basal ring; antennal ratio 1.35-1.53 $(144, \mathrm{n}=7)$. Palpal ratio 2.75-3.00 $(2.90, \mathrm{n}=8)$. Mandible with $6-8$ teeth. 

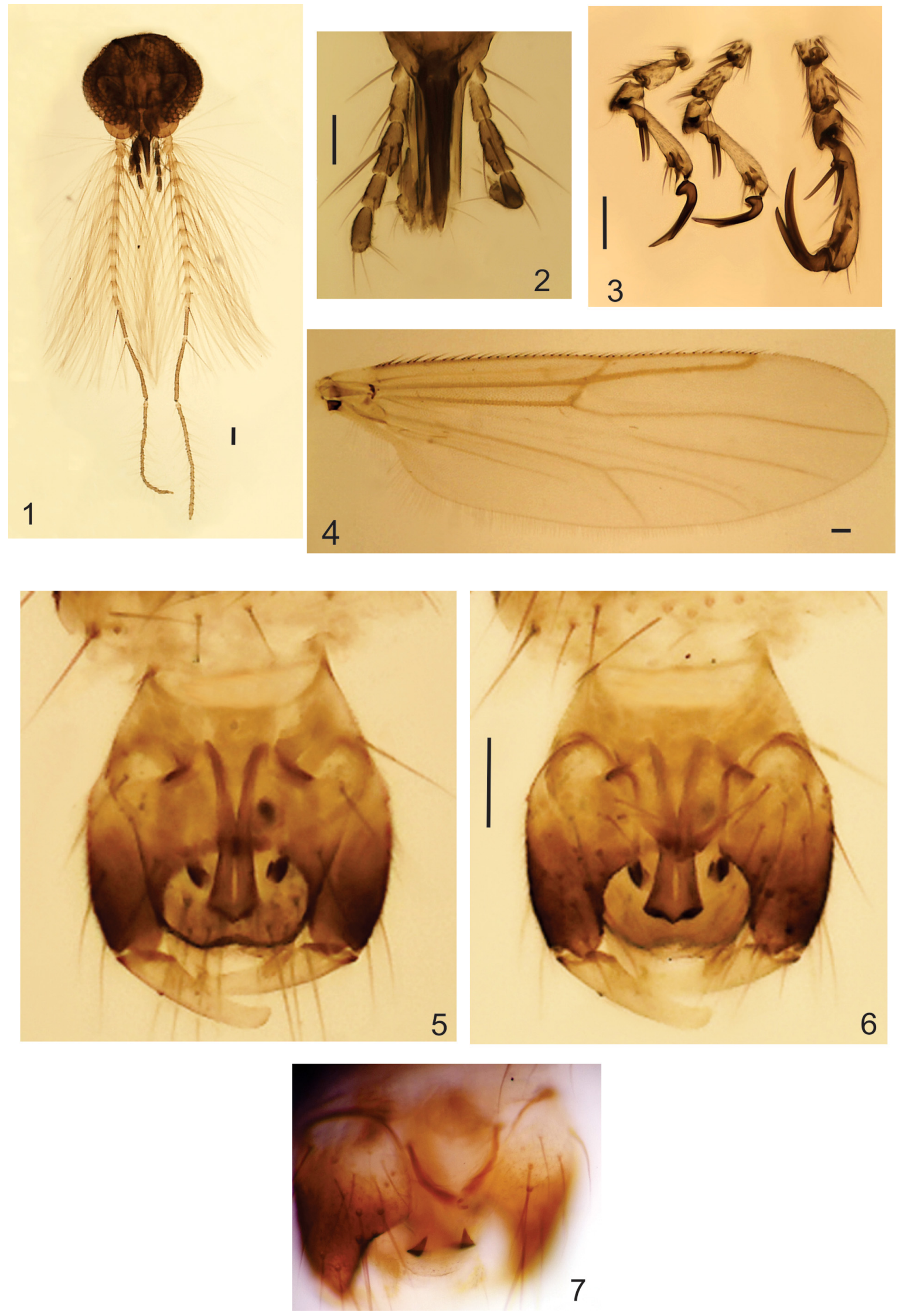

FIGURES 1-7. Stilobezzia (Eukraiohelea) elegantula (Johannsen). Male. 1. head, dorso-frontal view. 2. apex of proboscis and palpi. 3. tarsomeres 5 and claws. 4. wing. 5. genitalia, dorsal view. 6. genitalia, ventral view. 7. apices of parameres. Scale bars $0,05 \mathrm{~mm}$. 

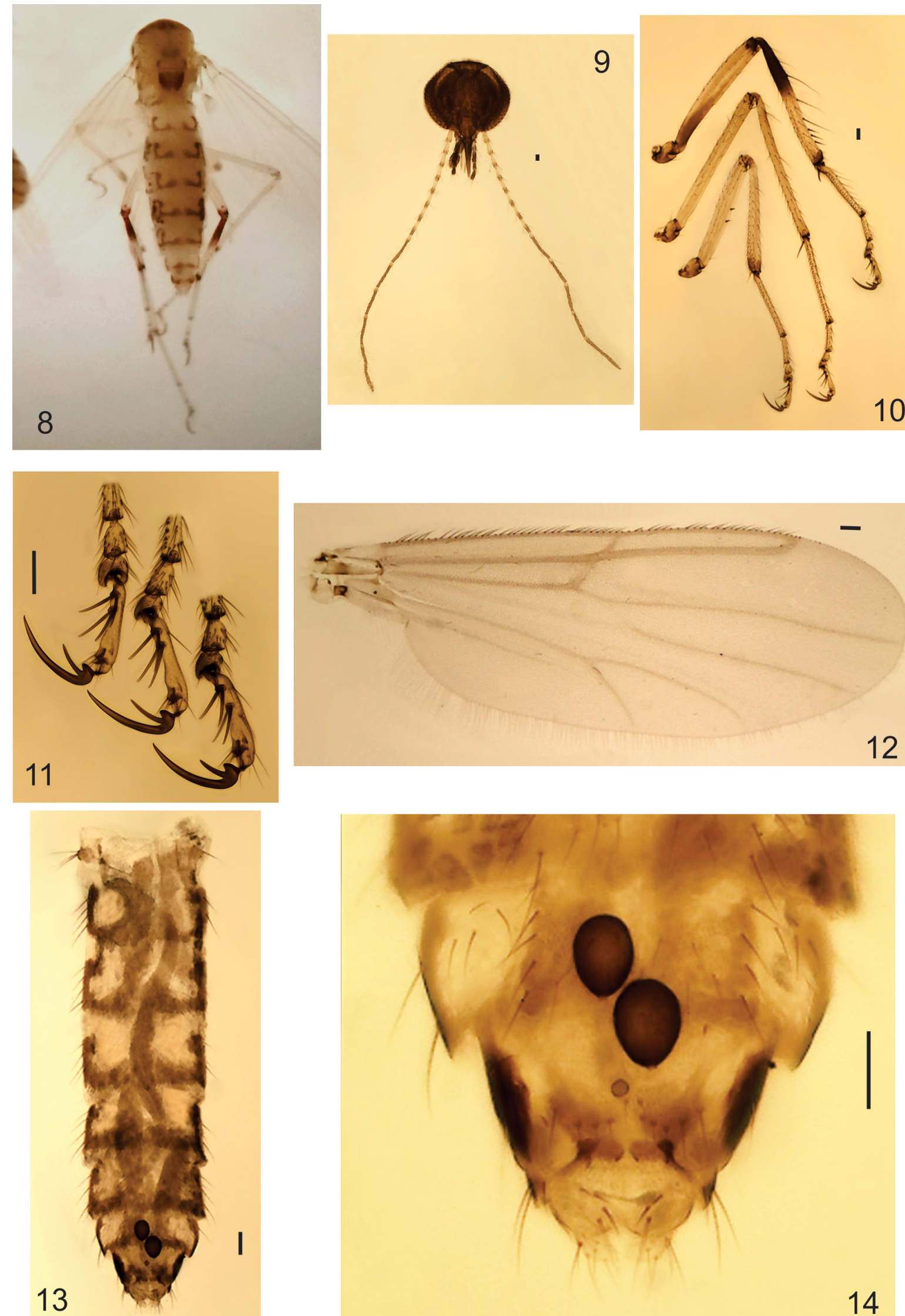

FIGURES 8-14. Stilobezzia (Eukraiohelea) elegantula (Johannsen). Female. 8. thorax and abdomen, dorsal view. 9. head, frontal view. 10. legs. 11. tarsomeres 5 and claws. 12. wing. 13. abdomen, ventral view. 14. sternites 7-10 of abdomen and spermathecae, ventral view. Scale bars: $0,05 \mathrm{~mm}$. 
Thorax. (Fig. 8). Legs (Fig. 10): fore femur with 2 ventral spines; tarsomere 5 of all legs with 2 pairs of batonnets (Fig. 11); fore tarsal ratio 2.21-2.36 $(2.30, \mathrm{n}=8)$, mid tarsal ratio 2.64-2.83 $(2.73, \mathrm{n}=8)$, hind leg tarsal ratio $2.30-2.70(2.53, \mathrm{n}=8)$; tarsomere 5 of all legs with claws almost as long as tarsomere with long basal tooth. Wing (Fig. 12) length $1.33-1.48(1.40, \mathrm{n}=8) \mathrm{mm}$, width $0.55-0.60(0.58, \mathrm{n}=8) \mathrm{mm}$; costal ratio $0.75-0.80(0.79$, $\mathrm{n}=8)$.

Abdomen (Figs. 8, 13). Lateral broad margins of segment 8 dark brown. Genitalia (Fig. 14): sternite 8 pale, with U-shaped posteromedian excavation; sternite 9 divided, each half slender with inner $1 / 3$ straight, sclerotized, margin recurved; sternite 10 pale with 3-4 pairs of setae; cercus rounded, short; two large, subequal, ovoid spermathecae with moderately wide, short necks, measuring $53-58(55, \mathrm{n}=5) \mu$ by $40-48(43, \mathrm{n}=5) \mu$ and $50-55$ $(50, n=5)$ by $38-45(40, n=5) \mu$; a small, round, rudimentary third spermatheca measuring $10(n=7) \mu$.

Distribution. Argentina (Chaco, Misiones), Brazil (Amazonas, Rio de Janeiro), Mexico, Panama, Paraguay, (?) Puerto Rico, USA (Kansas to Maryland, south to Louisiana and Florida).

Types. Types of Bezzia elegantula not designated by Johannsen (1907). Wirth \& Spinelli (1992) noted that females were labeled "Collected in July at electric light on bridge across Kansas river at Lawrence, Douglas County, Kansas, by E. S. Tucker.", in the Snow Entomological Collection, University of Kansas, Lawrence.

Material examined. 9 males, 10 females, as follows: 8 males, 9 females, BRAZIL, Rio de Janeiro, Casimiro

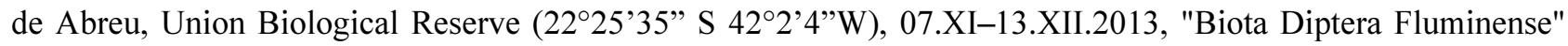
team col., Malaise trap (CCER); 1 male, 1 female, same data except 25.VIII-26.XI.2013 (CCER).

Discussion. The American species Stilobezzia (E.) elegantula is similar to S. (E.) punctifemorata Das Gupta \& Wirth, from Southeast Asia. The latter species can be clearly distinguished by the yellowish thorax with a peculiar dark brown pattern of coloration on the scutum, the presence of only one pair of batonnets on the female hind tarsomeres 5 and the aedeagal sclerites have a large expansion at their distomesal end. Furthermore, the presence of a rectangular sclerite located anterior to the parameres of $S$. elegantula resembles the male genitalia of $S$. (E.) brevicostalis Das Gupta \& Wirth, another species from Southeast Asia in which the parameres are enclosed within a dark band-like sclerotized bridge. This Asian species differs from S. elegantula by the stout black spine near the base of the male hind femur and the parameres have a large lateral lobe and a slender anterior arm.

Wirth (1953) noted that males of the subgenus Eukraiohelea have an aedeagus with a hyaline posterior membrane. We confirm that males of $S$. elegantula have such a hyaline membrane, but it extends from the dorsal inner margin of the gonocoxites to near the apex of the parameres and that the lateral margins are lightly sclerotized. Finally, in males of $S$. (E.) elegantula, the apices of the parameres are usually pointed, however in some specimens the apices are difficult to see and they are apparently blunt (Fig. 6).

\section{Stilobezzia (Eukraiohelea) proxima Cazorla \& Felippe-Bauer n. sp.}

(Figs. 15-28)

Diagnosis. The only Neotropical species of Stilobezzia (Eukraiohelea) of large size (wing length 1.50-1.82 mm) with pale yellowish coloration and the lateral margins of abdominal tergites with dark brown stripes. Male with stout gonocoxites; gonostyli short, swollen at mid portion with curved apex and pointed tip; apicolateral processes short, rounded and parameres with short, ventrally directed tip. Female with tarsomere 5 of fore and mid legs with 2 pairs of batonnets, tarsomere 5 of hind leg with 1 pair of batonnets and two ovoid spermathecae measuring 87-90 $\mu$.

Male (Fig. 15). Head (Fig. 16) dark brown. Antenna with flagellomeres 1-10 pale yellowish basally, light brown distally, flagellomeres 11-13 dark brown with light brown basal ring; flagellomere $132.5 \mathrm{X}$ longer than flagellomere 12; plume brown, poorly developed; antennal ratio 1.30. Palpus (Fig. 17) with segments 3-5 dark brown, 1-2 light brown; third segment elongate with subapical sensory pit; palpal ratio $3.50(n=2)$.

Thorax. Scutum brown (as Fig. 15, female), two faint yellowish lateral vittae extending posteriorly from paler humeral pits; scutellum pale yellowish except narrow lateral margins brown with 4 stout setae, 2-3 thinner setae; postscutellum brown. Legs pale yellowish; basal $1 / 3$ of mid tibia slightly darker; narrow apex of hind femur dark brown; basal 1/3, narrow apex of hind tibia dark brown; fore femur with 2-3 short stout ventral spines; tarsomere 1 of mid leg with slender, straight basal spine; tarsomere 1 of hind leg with stout, curved basal spine; hind tibial comb with 6 spines; fore leg tarsal ratio 2.41-2.45 $(2.43, \mathrm{n}=2)$; mid leg tarsal ratio 2.78-2.90 $(2.79, \mathrm{n}=2)$; hind leg 
tarsal ratio 2.69-2.88 (2.79, $\mathrm{n}=2)$; tarsomere 5 of all legs with 1 pair of batonnets (Fig. 18) and large claws with long basal tooth. Wing (Fig. 19) membrane hyaline; r-m crossvein oblique; cubital fork distal to level of base of $r-$ m crossvein; wing length $1.50-1.63(1.57, \mathrm{n}=2) \mathrm{mm}$, width $0.50(\mathrm{n}=2) \mathrm{mm}$; costal ratio $0.72-0.75(0.73, \mathrm{n}=2)$. Halter stem dark brown; basal half of knob dark brown, distal half pale.

Abdomen. Pale yellowish, lateral margins of tergites brown. Genitalia (Figs. 20-22): tergite 9 extending slightly beyond apex of gonocoxites, distal margin rounded with small mesal notch, apicolateral processes short with rounded apices, located laterad to the slender cerci (Fig. 22); sternite $92.50 \mathrm{X}$ broader than long, posterior margin not clearly distinguishable, apparently straight. Gonocoxite stout, $2.0 \mathrm{X}$ longer than greatest breadth, each with a hyaline membrane extending from the dorsal inner margin to nearly $2 / 3$ of the length of parameres, lateral broad margins of the membrane sclerotized, folded, connected dorsally by a broad, sclerotized transversal bridge; gonostylus pale yellowish, $0.60 \mathrm{X}$ the length of gonocoxite, swollen at mid portion, tip curved, pointed. Parameres separate, parallel; gonocoxal apodemes moderately sclerotized, broad, fused to dorsum of basal arms of parameres; basal arms stout, blade-like, apices rounded, divergent; distal portions slender, rod-like, closely approximated except on apices, which gradually taper to slightly broader ventrally recurved, pointed tips. Aedeagus represented by 2 arched sclerites; basal portion heavily sclerotized, recurved; subapical portion slightly swollen, more lightly sclerotized; distal portion pointed, tips overlapping.

Female. Similar to male, with the following notable sexual differences: Head (Fig. 23). Antenna with flagellomeres 1-8 pale yellowish basally, pale brown distally, flagellomeres 9-13 dark brown with pale basal ring; antennal ratio $1.73-1.92(1.82, \mathrm{n}=2)$. Palpal ratio 3.50-3.75 $(3.60, \mathrm{n}=2)$. Mandible with $7-8$ teeth.

Thorax. Legs (Fig. 24): fore femur with 2-4 short, stout ventral spines; tarsomere 5 of fore and mid legs with 2 pairs of batonnets, tarsomere 5 of hind leg with 1 pair of batonnets (Fig. 25); fore leg tarsal ratio 2.33-2.44 (2.38, $\mathrm{n}=2)$; mid leg tarsal ratio 2.65-2.72 $(2.68, \mathrm{n}=2)$; hind leg tarsal ratio 2.75-2.86 $(2.80, \mathrm{n}=2)$; claws slightly shorter than their respective tarsomeres 5, with moderately long basal tooth. Wing (Fig. 26) length 1.75-1.82 (1.78, $\mathrm{n}=2) \mathrm{mm}$, width $0.65-0.68(0.66, \mathrm{n}=2) \mathrm{mm}$; costal ratio 0.76-0.77 $(0.76, \mathrm{n}=2)$.

Abdomen. (Fig. 27). Broad lateral margins of segment 8 dark brown. Genitalia (Fig. 28): sternite 8 pale, narrow, with U-shaped posteromedian excavation; sternite 9 halves heavily sclerotized, anterior margins straight, posterior margins curved, apices broader, decumbent; sternite 10 pale with 3-4 pairs of setae; cercus rounded, short. Two subequal, ovoid spermathecae with short, moderately wide necks, measuring 90 by $57(\mathrm{n}=2) \mu$ and 87 by $57(\mathrm{n}=2) \mu$; a small, spheroid rudimentary third spermatheca measuring $12-15(13.5, \mathrm{n}=2) \mu$.

Distribution. Brazil (Rio de Janeiro).

Types. Holotype male, labeled "Holotype Stilobezzia (Eukraiohelea) próxima Cazorla and Felippe-Bauer,

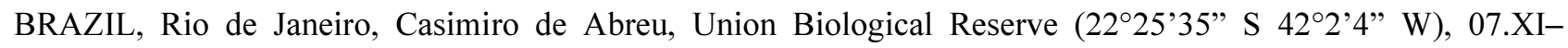
13.XII.2013, "Biota Diptera Fluminense" team col, Malaise trap, (CCER). Allotype female, 1 male paratype with same data as holotype (CCER); other paratypes, 1 male, 1 female with same data except 25.VIII-26.XI.2013", (CCER).

Etymology. The species name proxima (from Latin = near), refers to the resemblance of this new species with Stilobezzia (E.) elegantula and $S$ (E.) quasielegantula n. sp. described below.

Discussion. Stilobezzia (E.) proxima n. sp. greatly resembles $S$. (E.) elegantula and $S$. (E.) quasielegantula n. sp. by its overall pale yellowish coloration, but it readily differs from two dark brown species, $S$. amnigena and $S$. dorsofasciata. Females of $S$. proxima are distinguished from the above two pale species in the subgenus Eukraiohelea by several characters: the larger wing (female wing length $1.33-1.48 \mathrm{~mm}$ in elegantula and 1.30$1.37 \mathrm{~mm}$ in $S$. quasielegantula); larger spermathecae (spermathecae $50-58 \mathrm{~mm}$ long in S. elegantula and 48-65 $\mathrm{mm}$ long in quasielegantula); the absence of dark marks on the abdominal tergites (dark brown L-shaped marks in S. elegantula, dark brown transverse bands with pale spots in S. quasielegantula ), and only one pair of batonnets on tarsomere 5 of the hind leg (two pairs of batonnets on tarsomere 5 of the hind leg in elegantula). The males of this new species and those of $S$. quasielegantula have well developed apicolateral processes, which are apparently absent in S. elegantula; the gonostylus is swollen at midportion, whereas it is subapically swollen in $S$. quasielegantula, and in S. elegantula is slender; finally, the apicolateral process are short and rounded (they are moderately elongate and lobe-shaped in S. quasielegantula, but are absent in S. elegantula). 


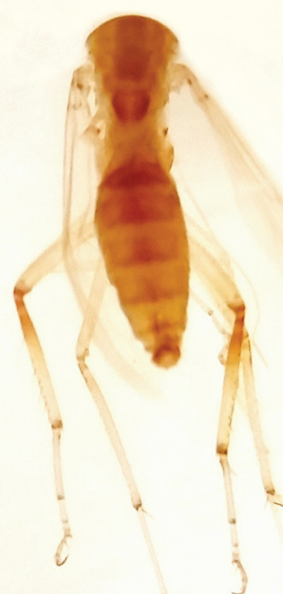

15

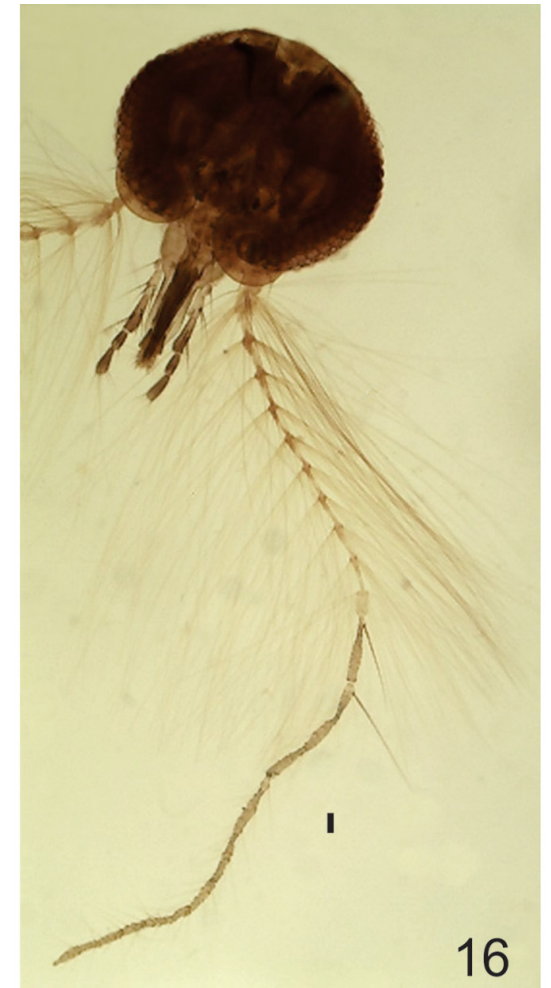

16
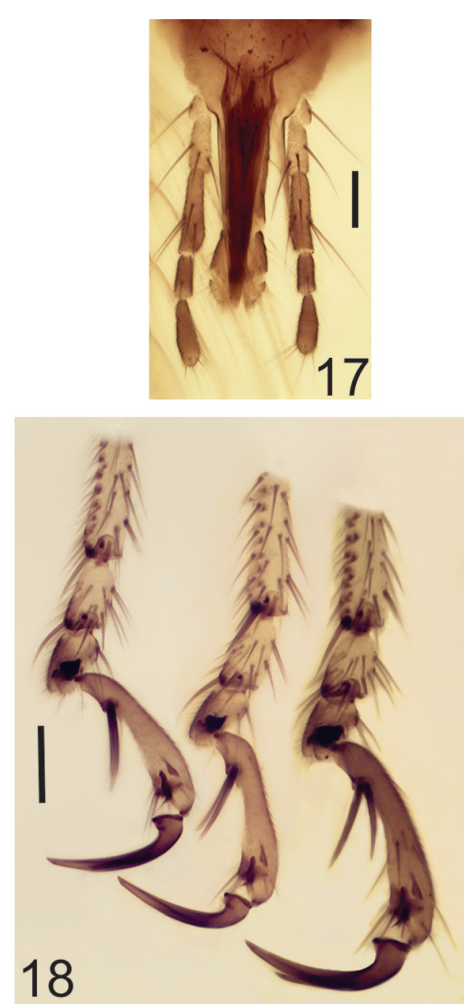
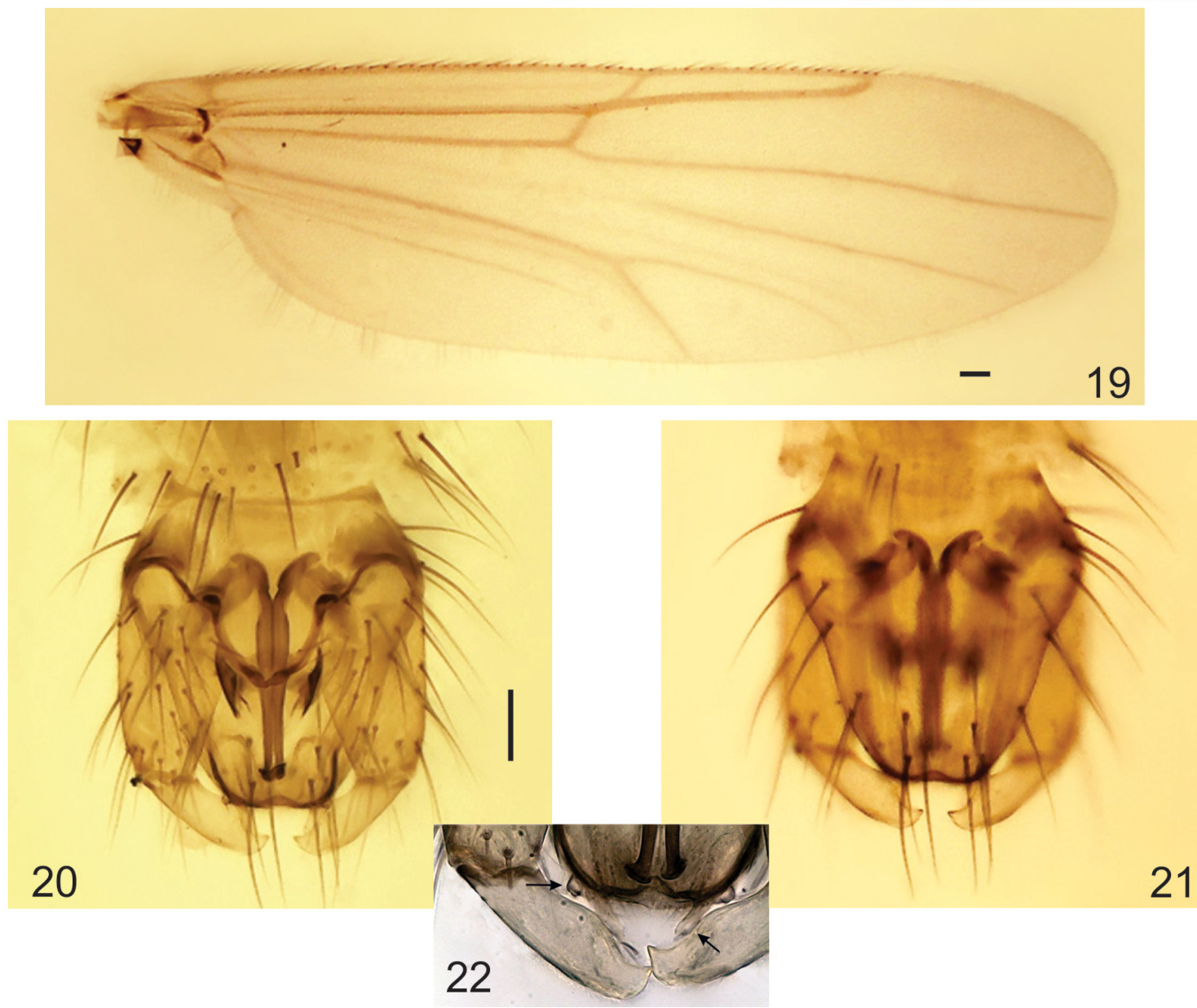

FIGURES 15-22. Stilobezzia (Eukraiohelea) proxima Cazorla \& Felippe-Bauer n. sp. Male. 15. thorax and abdomen, dorsal view. 16. head, frontal view. 17. apex of proboscis and palpi. 18. tarsomeres 5 and claws. 19. wing. 20. genitalia, ventral view. 21 genitalia, dorsal view. 22 detail of cerci and apicolateral processes. Scale bars: 0,05 $\mathrm{mm}$. 

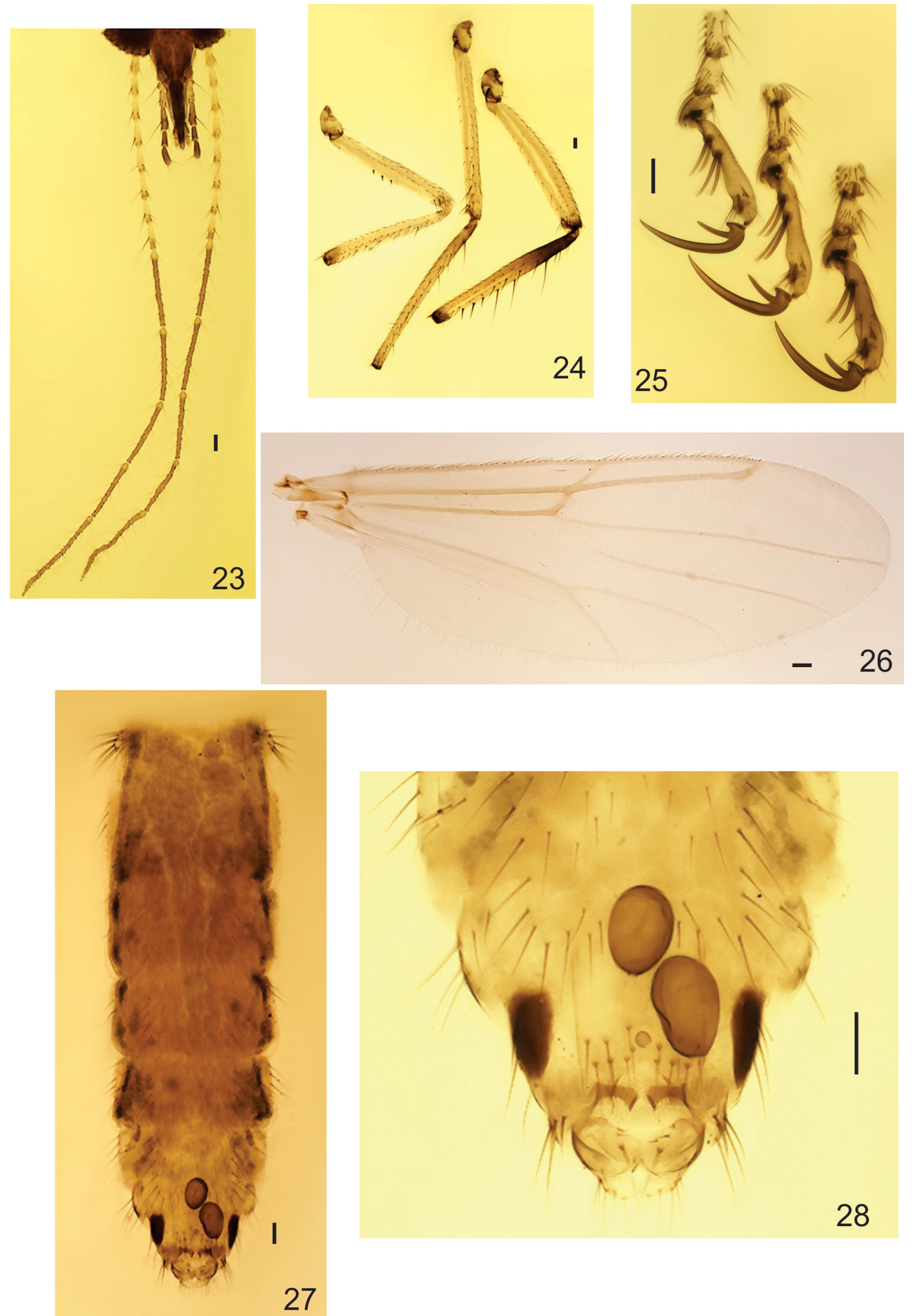

FIGURES 23-28. Stilobezzia (Eukraiohelea) proxima Cazorla \& Felippe-Bauer n. sp. Female. 23. head, frontal view. 24. trochanters, femora and tibiae. 25. tarsomeres 5 and claws. 26. wing. 27. abdomen, ventral view. 28. sternites 6-10 of abdomen and spermathecae, ventral view. Scale bars: $0,05 \mathrm{~mm}$. 


\section{Stilobezzia (Eukraiohelea) quasielegantula Cazorla \& Felippe-Bauer n. sp.}

(Figs. 29-42)

Diagnosis. The only Neotropical species of Stilobezzia (Eukraiohelea) of medium size (wing length 1.17-1.37 $\mathrm{mm}$ ) with general coloration pale yellowish and brown transverse bands on abdominal tergites with two small, round clear spots on their mid portions. Male gonocoxite with a conspicuous sclerotized membrane arising from dorsal inner margin; gonostylus swollen subapically with curved, sclerotized pointed apical projection; and apices of parameres greatly elongate and recurved $100^{\circ}$. Female with tarsomere 5 of fore and mid legs with 2 pairs of batonnets and tarsomere 5 of hind leg with only 1 pair.

Male. Head. (Fig. 29) dark brown. Antenna with flagellomeres 1-10 pale brown basally, brown distally, flagellomeres 11-13 dark brown with pale brown basal ring; flagellomere 13 more than twice as long as 12; plume brown, well developed; antennal ratio 1.07-1.23 (1.15, $\mathrm{n}=7)$. Palpus (Fig. 30) dark brown; third segment elongate with small, shallow subapical sensory pit; palpal ratio 3.00-3.70 $(3.47, \mathrm{n}=10)$.

Thorax. Scutum pale brown (as Fig. 42, female), prescutellar depression light yellowish; scutellum light yellowish with 4 stout, 1-2 thinner setae; postscutellum brown. Legs yellowish; narrow apex of hind femur, basal $1 / 3$, narrow apex of hind tibia dark brown; fore femur with 2-3 short, stout ventral spines; tarsomere 1 of mid leg with long, slender, straight basal spine; tarsomere 1 of hind leg with stout, slightly curved basal spine; hind tibial comb with 5-6 spines; fore leg tarsal ratio 2.50-2.67 (2.60, $\mathrm{n}=9)$; mid leg tarsal ratio 2.75-3.04 (2.92, $\mathrm{n}=7)$; hind leg tarsal ratio 2.62-2.85 (2.72, $\mathrm{n}=10)$; tarsomere 5 of all legs with 1 pair of batonnets (Fig. 31), claws large, with long basal tooth, claws of hind leg longest. Wing (Fig. 32) membrane hyaline; r-m crossvein oblique; cubital fork distal to level of base of r-m crossvein; wing length $1.17-1.25(1.20, \mathrm{n}=10) \mathrm{mm}$, width $0.40-0.45(0.40, \mathrm{n}=10)$ $\mathrm{mm}$; costal ratio $0.70-0.75(0.72, \mathrm{n}=10)$. Halter dark brown.

Abdomen. Tergites with broad transverse dark brown bands with two small, round pale spots on their midlines; sternites dark yellowish. Genitalia (Figs. 33-35): tergite 9 extending slightly beyond apices of gonocoxites, distal margin rounded with very shallow mesal notch; apicolateral processes lobate, moderately elongate, slender, overlapping along their inner margins with the broad, rectangular cerci (Fig. 35); sternite $92.80 \mathrm{X}$ broader than long, posteromedian portion not clearly distinguishable. Gonocoxite $1.8 \mathrm{X}$ longer than greatest breadth, stout proximally, nearly triangular, tapering distally with a sclerotized membrane extending from dorsal inner margin to apices of parameres, lateral margins straight, outer margins are slightly curved distally they don't converge; gonostylus light brown, stout, $0.70 \mathrm{X}$ the length of gonocoxite, swollen subapically, apex with a sclerotized, curved, pointed projection. Parameres parallel, gonocoxal apodemes stout, bilobed; proximal 1/4 portions slender, sclerotized, distal $3 / 4$ portions broader, apices elongate, greatly divergent, recurved $100^{\circ}$, tapering to pointed tips. Aedeagus (Fig. 34) represented by 2 arched, slender sclerites, each with basal portion curved, sclerotized, distal portion rounded, sclerotized.

Female (Fig. 42). Similar to male, with the following notable sexual differences: Head (Fig. 36). Antenna with proximal $1 \frac{1}{2}$ of flagellomeres $1-8$ pale brown, distal 1/2 dark brown, flagellomeres 9-13 dark brown with pale basal ring; antennal ratio $1.42-1.62(1.53, \mathrm{n}=8)$. Palpal ratio 3.10-4.00 $(3.60, \mathrm{n}=8)$. Mandible with $7-8$ teeth.

Thorax. Legs (Fig. 37): tarsomere 5 of fore leg, mid leg with 2 pairs of batonnets, hind leg with 1 pair of batonnets (Fig. 38); fore leg tarsal ratio 2.50-3.08 (2.65, $\mathrm{n}=9)$; midleg tarsal ratio 2.77-3.04 (2.88, $\mathrm{n}=9$ ); hind leg tarsal ratio 2.50-3.00 $(2.74, \mathrm{n}=9)$; claws of all legs almost as long as tarsomere 5 , fore and mid claws slenderer than hind claw, all with moderately long basal tooth that is shortest on hind claw. Wing (Fig. 39) length 1.30-1.37 $(1.32, \mathrm{n}=9) \mathrm{mm}$, width $0.47-0.55(0.52, \mathrm{n}=9) \mathrm{mm}$; costal ratio $0.73-0.78(0.76, \mathrm{n}=9)$.

Abdomen (Fig. 40): Proximal 2/3 or more tergites brown, distal portions lighter; broad lateral margins of tergites 8 dark brown. Genitalia (Fig. 41): sternite 8 light brown, with narrow U-shaped posteromedian excavation; sternite 9 halves heavily sclerotized, of similar shapes to those of $S$. proxima n. sp.; sternite 10 pale brown with 34 pairs of setae; cercus short with rounded apex. Two unequal-size, ovoid spermathecae with very short wide necks, measuring $50-65(57, \mathrm{n}=8) \mu$ by $40-45(42, \mathrm{n}=8) \mu$ and $48-58(50, \mathrm{n}=8)$ by $38-40(40, \mathrm{n}=8) \mu$; plus a small, round rudimentary third spermatheca measuring $10-12(10.7, \mathrm{n}=8) \mu$.

Distribution. Brazil (Rio de Janeiro).

Types. Holotype male, labeled "Stilobezzia (Eukraiohelea) quasielegantula Cazorla and Felippe-Bauer,

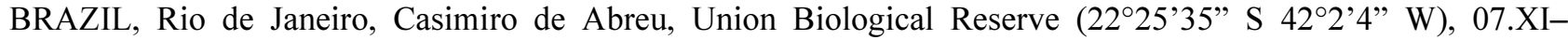
13.XII.2013, "Biota Diptera Fluminense" team col, Malaise trap", (CCER). Allotype female, 30 other paratypes: 9 
males, 8 females with same data as holotype ( 7 males, 6 females, CCER; 2 males, 2 females, MLPA); 1 male, 1 female with same data except 25.VIII-26.XI.2013 (CCER).
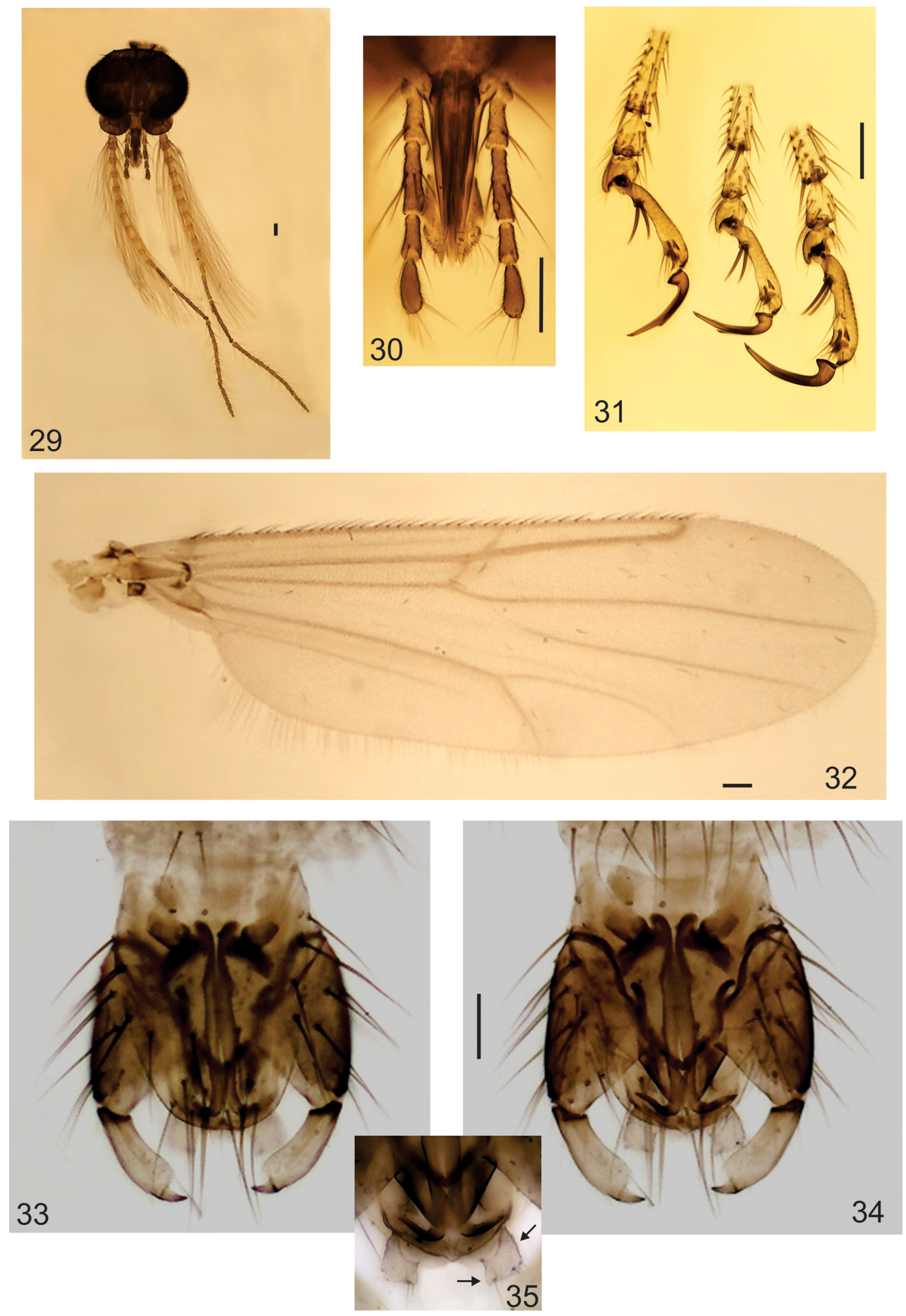

FIGURES 29-35. Stilobezzia (Eukraiohelea) quasielegantula Cazorla \& Felippe-Bauer n. sp. Male. 29. head, dorso-frontal view. 30. proboscis and palpi. 31. tarsomeres 5 and claws. 32. wing. 33. genitalia, dorsal view. 34. genitalia, ventral view. 35 detail of cerci and apicolateral processes. Scale bars: $0,05 \mathrm{~mm}$. 

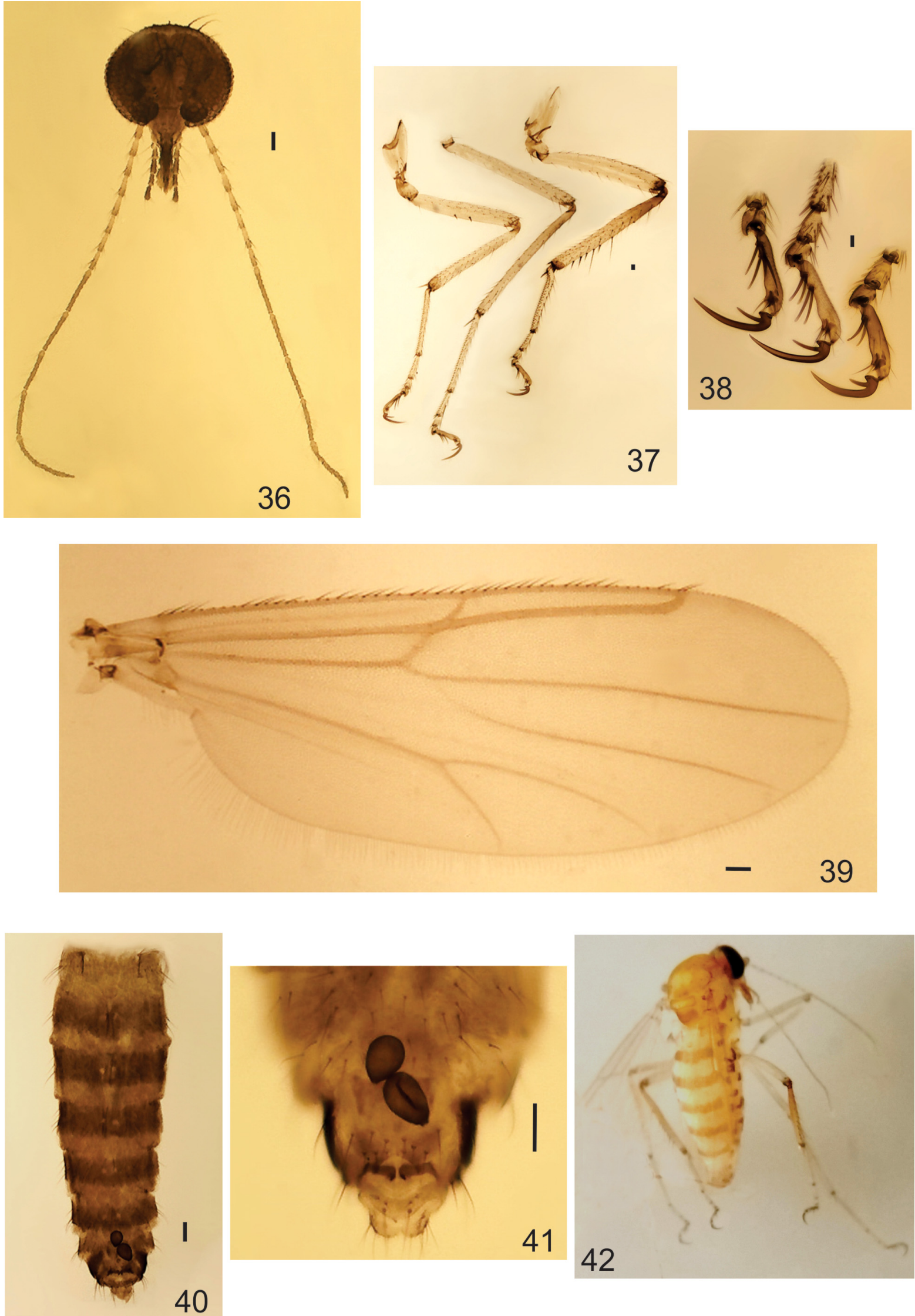

40

FIGURES 36-42. Stilobezzia (Eukraiohelea) quasielegantula Cazorla \& Felippe-Bauer n. sp. Female. 36. head, frontal view. 37. legs. 38. tarsomeres 5 and claws 39 wing. 40. abdomen, ventral view. 41. sernites 7-10 of abdomen and spermathecae. 42. habitus, dorsolateral view. Scale bars: $0,05 \mathrm{~mm}$. 


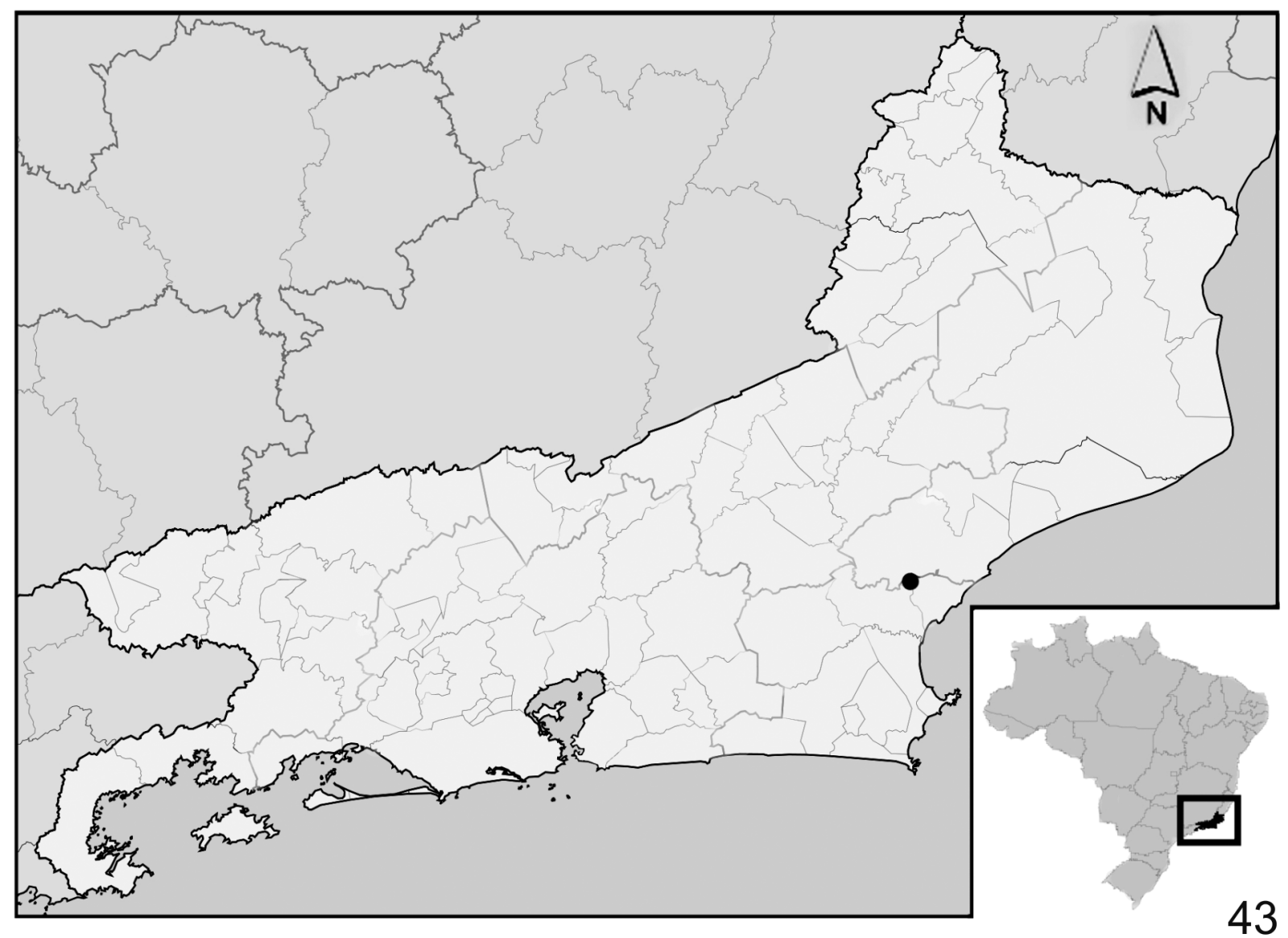

FIGURES 43. Map of Rio de Janeiro State with location of the Union Biological Reserve (black circle) and inset of this state in Brazil.

Etymology. The species name quasielegantula refers to the great resemblance of this new species with its congener $S$. (E.) elegantula.

Discussion. Stilobezzia (E.) quasielegantula $\mathrm{n}$ sp. is very similar to $S$. (E.) elegantula and the new species $S$. (E.) proxima. Characters for distinguishing these two species from this new species are in key and in the discussion section of the latter species.

\section{Acknowledgements}

This work was funded by the Fundação Oswaldo Cruz and Consejo Nacional de Investigaciones Científicas y Técnicas (CONICET). We are grateful to William L. Grogan for reviewing the manuscript, to Tiago do Nascimento da Silva for his help with the photomicrographs, and to Fundação de Amparo à Pesquisa do Estado do Rio de Janeiro (Faperj) for their financial support to the study of the Diptera fauna from Rio de Janeiro ("Apoio ao Estudo da Biodiversidade do Estado do Rio de Janeiro"- 2012 Biota-RJ).

\section{References}

Borkent, A. (2016) World species of biting midges (Diptera: Ceratopogonidae). Available from: http://wwx.inhs.illinois.edu/ files/1114/2384/5200/CeratopogonidaeCatalog.pdf (accessed 9 August 2017)

Borkent, A. \& Grogan, W. (2009) Catalog of the New World Biting Midges North of Mexico (Diptera: Ceratopogonidae). Zootaxa, 2273, 1-48.

Borkent, A. \& Spinelli, G.R. (2007) Neotropical Ceratopogonidae (Diptera: Insecta). In: Adis, J., Arias, J.R., Rueda-Delgado, 
G. \& Wantzen, K.M. (Eds.), Aquatic Biodiversity in Latin America (ABLA). Vol. 4. Pensoft, Sofia-Moscow, pp. 1-198.

Borkent, A., Spinelli, G.R. \& Grogan, W.L. (2009) Ceratopogonidae (biting midges, purrujas). In: Brown, B.V., Borkent A., Cumming J.M., Wood, D.M., Woodley, N.E. \& Zumbado, M.A. (Eds.), Manual of Central America Diptera. Vol. 1. NRC Research Press, Ottawa, Ontario, pp. 407-435.

Grogan, W.L., Hribar, L.J., Murphree, C.S. \& Cilek, J.E. (2010) New records of biting and predaceous midges from Florida, including species new to the fauna of the United States (Diptera: Ceratopogonidae). Insecta Mundi, 0147, 1-59.

Johannsen, O.A. (1907) Some new species of Kansas Chironomidae. In: Tucker, E.S., Some results of desultory collecting of insects in Kansas and Colorado. Bulletin of the University of Kansas, Science Bulletin, 1907, pp. 109-112.

Johannsen, O.A. (1934) New species of North American Ceratopogonidae and Chironomidae. Journal of the New York Entomological Society, 42, 343-352.

Johannsen, O.A. (1943) Two new species of American Ceratopogonidae (Diptera). Annals of the Entomological Society of America, 36, 761-762. https://doi.org/10.1093/aesa/36.4.761

Kieffer, J.J. (1917) Chironomides d'Amérique conservés au Musée National Hongrois de Budapest. Annales historiconaturales Musei nationalis hungarici, 15, 175-228.

Lane, J. \& Forattini, O.P. (1956) Neotropical Stilobezzia Kieffer, 1911 I. Nine new Panamanian species (Diptera, Nematocera, Ceratopogonidae). Revista Brasileira de Malariologia, 8, 207-226.

Lane, J. \& Forattini, O.P. (1961) Neotropical Stilobezzia, 1911 III. Key for the adults of this genus and description of one new species (Diptera, Ceratopogonidae). Revista Brasileira de Entomología, 10, 83-94.

Malloch, J.R. (1914) Synopsis of the genus Probezzia, with description of a new species. Proceedings of the Biological Society of Washington, 27, 137-140.

Malloch, J.R. (1915) The Chironomidae, or midges, of Illinois, with particular reference to the species occurring in the Illinois river. Bulletin of the Illinois State Laboratory of Natural History, 10, 275-543.

Santarém, M.C.A. \& Felippe-Bauer, M.L. (2017) Brazilian species of biting midges (Diptera: Ceratopogonidae). Available from: http://www.fiocruz.br/ioc/media/especies_maruins_brasil_2017_publicacoes.pdf (accessed 19 May 2017)

Spinelli, G.R. \& Cazorla, C.G. (2005) The subgenus Stilobezzia (Eukraiohelea) in Argentina and Paraguay (Diptera: Ceratopogonidae). Revista de la Sociedad Entomológica Argentina, 64 (3), 72-74.

Torreias S.R.S., Ferreira-Keppler, R.L. \& Ronderos, M.M. (2014) Biting midges (Ceratopogonidae: Diptera) present in aquatic macrophytes from wetlands of Marchantaria Island, Iranduba, Central Amazonia, Brazil. Journal of Natural History, 48 (1-2), 109-122. https://doi.org/10.1080/00222933.2013.791934

Wilkening, A.J., Kline, D.L. \& Wirth, W.W. (1985) An annotated checklist of the Ceratopogonidae (Diptera) of Florida with a new synonymy. Florida Entomologist, 68, 511-537. https://doi.org/10.2307/3494854

Wirth, W.W. (1953) Biting midges of the heleid genus Stilobezzia in North America. Proceedings of the United States National Museum, 103, 57-58. https://doi.org/10.5479/si.00963801.103-3316.57

Wirth, W.W. (1974) Family Ceratopogonidae. In: A catalog of the Diptera of the American south of the United States, Fasc. 14, pp. $1-89$.

Wirth, W.W. \& Grogan, W.L. (1981) Natural History of Plummers Island, Maryland XXV. Biting midges (Diptera: Ceratopogonidae). 3. The species of the tribe Stilobezziini. Bulletin of the Biological Society of Washington, 5, 1-102.

Wirth, W.W. \& Marston, N. (1968) A method for mounting small insects on microscope slides in Canada balsam. Annals of the Entomological Society of America, 61, 783-784. https://doi.org/10.1093/aesa/61.3.783

Wirth, W.W. \& Spinelli, G.R. (1992) American predaceous midges of the subgenus Eukraiohelea of Stilobezzia (Diptera: Ceratopogonidae). Florida Entomologist, 75, 342-349. https://doi.org/10.2307/3495855 